International Research Journal of Management, IT \& Social Sciences
Available online at https://sloap.org/journals/index.php/irjmis/
Vol. 6 No. 4, July 2019, pages: 180 188
ISSN: 2395-7492
https://doi.org/10.21744/irjmis.v6n4.676

\title{
Tri Hita Karana Culture and Organizational Commitments Moderate: Effect of Participation on Budgetary Slack
}

\begin{tabular}{|c|c|}
\hline & $\begin{array}{l}\text { Gede Adi Sukayana } \\
\text { I.G.A.M Asri Dwija Putri }\end{array}$ \\
\hline Article history: & Abstract \\
\hline $\begin{array}{l}\text { Received: } 27 \text { March } 2019 \\
\text { Accepted: } 31 \text { May } 2019 \\
\text { Published: } 28 \text { June } 2019\end{array}$ & $\begin{array}{l}\text { This research was conducted in order to obtain evidence of how the effect of } \\
\text { budgetary participation on budgetary slack in Bali Provincial OPD with the tri } \\
\text { hita karana culture and organizational commitment as a moderating variable. } \\
\text { This research was conducted in } 45 \text { Regional Organizations in Bali Province. } \\
\text { The research sample was determined by purposive sampling method and based } \\
\text { on the specified criteria obtained a total sample of } 203 \text { respondents. Data }\end{array}$ \\
\hline Keywords: & $\begin{array}{l}\text { collection is done using the questionnaire method. The hypothesis is tested } \\
\text { using simple regression analysis techniques and the Moderating Regression }\end{array}$ \\
\hline $\begin{array}{l}\text { budgetary participation; } \\
\text { budgetary slack; } \\
\text { culture; } \\
\text { organizational commitment; } \\
\text { tri hita karana; }\end{array}$ & $\begin{array}{l}\text { Analysis. The results showed that budgetary participation had a positive effect } \\
\text { on budgetary slack. The Tri Hita Karana culture shows that weakening the } \\
\text { positive effect of budgetary participation on budgetary slack and } \\
\text { organizational commitment shows that it weakens the positive effect of } \\
\text { budgetary participation on budgetary slack. }\end{array}$ \\
\hline
\end{tabular}

2395-7492@ Copyright 2019. The Author. This is an open-access article under the CC BY-SA license (https://creativecommons.org/licenses/by-sa/4.0/) All rights reserved.

\section{Author correspondence:}

Gede Adi Sukayana,

Faculty of Economics and Business, Udayana University, Denpasar, Indonesia.

Email address: rasumaputri80@gmail.com

\section{Introduction}

Budgetary slack often occurs in the stages of regional budget planning and preparation, because budgeting is often dominated by executive and legislative interests, and does not reflect the needs of the people of Kartiwa (2004). In this case, the executive as an agent carries out a budget that will be ratified by the legislature which acts as the principal.

Budgetary slack is the difference between the amount of budget reported by an agent and the best number of estimates from the organization (Anthony \& Govindaradjan, 2007). In addition, Young (1985), also argues that budgetary slack is an action where agents overestimate productive abilities by estimating lower income and higher costs when given the opportunity to choose work standards so as to improve performance. According to Tagwireyi (2012), managers tend to budget lower-income (understated) and budget for higher (overstated) costs. Budgetary slack

\footnotetext{
${ }^{a}$ Faculty of Economics and Business, Udayana University, Denpasar, Indonesia ${ }^{\mathrm{b}}$ Faculty of Economics and Business, Udayana University, Denpasar, Indonesia
} 
is beginning to be seen as an important problem because the higher the budgetary slack that occurs in an organization, it causes a lack of effective management performance of the organization (Yilmaz \& Ozer, 2011).

The Regional Budget of Bali Province reflects the existence of a budgetary slack because from the data of 5 (five) years the regional income budget realization is always higher than the stipulated income budget and the realization of the regional budget is always lower than the stipulated regional budget. This can have a negative impact on public sector organizations because the allocation of resources and government performance is less than optimal. Managers tend to submit budgets by lowering income and raising costs compared to the best estimates from those proposed so that targets will be more easily achieved. Chin-Chun et al., (2013), states that when managers participate in budgeting, the tendency to do budgetary slack will increase. Such conditions certainly cannot be left unchecked if there is an expectation gap between the legislature, the executive, and the agency head, which in the end the organization's goal congruence is increasingly questionable. In this regard, through this research, it is desirable to know the factors that should be suspected of having the potential to have a strong impact on budgetary slack, namely: budgetary participation.

Participation in budgeting is a budgeting process where there is a collection of individuals who participate in the budgeting process and have an effect on the target of a budget (Brownell, 1982). The hope of implementing participatory budgeting is that the budget prepared can be carried out well on par with the capabilities of budget users.

The budgeting system has undergone several changes to the government sector since the enactment of the Act. No. 17 of 2003 concerning State Finances where previously the top-down method was bottom-up. This means that budgeting is based on the active participation of government organizational units from the lower level to the upper level in delivering the performance budget targets achieved. The participation of subordinates as budget implementers participates in preparing budgets so that harmony and harmony with organizational goals are created.

Behind expectations for participation in budgeting, there are weaknesses that can occur if budgeting involves agents. An agent who participates in the budgeting process can cause the implementation of the budget not to run according to the agency's capacity, this is called budgetary slack. Schiff \& Lewin (1970), say budgetary slack is defined as an imbalance between actual budget potential and the budget prepared. According to Young (1985), budgetary slack is carried out by agents by minimizing the maximum ability of its performance when agents have the opportunity to determine the standard of work. Budgetary slack indicates an imbalance in budgeting where there is a decrease in the income budget and an increase in budgeted expenditure.

The budgeting process can be done with the top-down, bottom-up, and participatory budgeting methods of Hapsari (2011). This participatory budgeting is often associated with budgetary slack. Previous studies that have examined the effect of budgetary participation on budgetary slack state inconsistent results, including Young (1985); Lukka (1988); Falikhatun (2008); Sugiwardani (2012); April \& Hidayani, 2012; Mahadewi (2014); Lestari (2015); and Erina (2016), found that high budgetary participation can lead to budgetary slack. In contrast to the findings of Merchant (1985); Dunk (1993); Karsam (2013); Pamungkas et al., (2014 ); Srimuliani et al., (2014); and Sujana (2010) ; Aditya \& Kusuma, (2019); Dewi et al., (2018), stated that high budget participation can reduce the occurrence of budgetary slack. Responding to the phenomenon of budgetary slack, not only from economic perspectives that need to be considered and evaluated but also viewed from a social, behavioral, and managerial perspective in the overall organizational context of Ajibolade et al., (2013) \& Pratiwi et al., (2019).

Based on the exposure of the study, the effect of budgetary participation on budgetary slack was found to be variable/inconsistent or controversial, which was allegedly due to other factors that effect the relationship between independent variables and dependent variables. Govindarajan (1986), states that the possibility of the absence of unity of research results depends on certain factors or better known as contingency factors. Murray (1990), explains that in order to reconcile conflicting results a contingency approach is needed to identify other variables that act as moderators or mediators in the research model. Conceptually and the results of empirical research, there are several variables that are thought to play a role in moderating the effect of budgetary participation on the budgetary slack, among them worthy of consideration, namely the organizational commitment and culture of Tri Hita Karana.

To maximize the budget in an organization, basically, the organization must also have the view that its performance is effect by good values derived from self-strength, work environment, and relations between fellow employees of Adiputra (2014). Therefore, the effect of local culture is very important, a culture that is already known and is always carried out by everyone in the area.

This research itself is a development of research conducted by Wiyantoro \& Sabeni (2007), which examines the relationship between management control systems and dysfunctional behavior in relation to the budget, using the dimensions of national culture as a moderating variable. The developed aspect is to replace cultural variables, which

Sukayana, G. A., \& Putri, I. A. D. (2019). Tri hita karana culture and organizational commitments moderate: effect of participation on budgetary slack. International Research Journal of Management, IT and Social Sciences, 6(4), 180-188. https://doi.org/10.21744/irjmis.v6n4.676 
previously referred to the national cultural dimension according to Hofstede, with the local culture that developed in Bali, namely the Tri Hita Karana Culture.

\section{Literature Review}

This study explains the effect of budgetary participation on budgetary slack which is moderated by the organizational commitment and tri hita karana culture. The theory underlying this research is the agency theory proposed by (Jensen \& Meckling, 1976). This theory explains that contractual relations between principals and agents regarding contracts between one or more people acting as principals appoint other people as agents to carry out services for the principal's interests including delegating power in decision-making. The relevance of the theory of religion with this research is in the context of policymaking, in which the legislature as principal gives authority to the executive as an agent to make new policy proposals and ends after the proposal is accepted or rejected. In this case, the agent tends to do a budget slack because it maintains its relationship with the principal and secures the job and position or position in the government. Therefore to minimize the slack that might occur in the budgeting process, employers are better off involving subordinates in budgeting because subordinates are more aware of the problems that occur in the field and if subordinates are involved in the budgeting process will increase confidence and strong support for the goals and objectives organization wants. With a strong organizational commitment from each individual, the employee will work with dedication because employees who have a high commitment assume that the important thing to achieve is the achievement of goals in the organization itself and the Tri Hita Karana culture that is used as the basic teachings of how humans must behave expected to improve human moral and ethics in social life. By understanding the nature of human guidance to always be in harmony with God Almighty (parahyangan), with fellow humans (pawongan) and with the environment (palemahan), then humans will not be possible to do actions that cause harm or destruction to others including organizations.

\section{Relationship between Budgetary participation and Budgetary Slack}

Some studies that say that budget participation has a positive effect on budgetary slack include Falikhatun (2008); Mahadewi (2014); Erina (2016); and Wati et al., (2017). Strengthened by the opinion of Sandrya (2013) participation in budgeting in the public sector will create budgetary slack. The argument put forward is that the higher the participation given to subordinates, the subordinates tend to try to make their budget easy to achieve, one way to do that is to loosen the budget or create budgetary slack. Based on the theoretical study above, the hypothesis formulated is

H1: Budgetary participation has a positive effect on budgetary slack.

\section{Organizational Commitment on the Positive Relationship of Budgetary participation at the Budgetary Slack}

Wardani (2016), states that employees who have a commitment to their organization will work with dedication because employees who have a high commitment assume that the important thing to achieve is the achievement of tasks in the organization. Previous research such as Nouri \& Parker (1996); Lestari (2015); and Nitiari (2014), have used organizational commitment variables as moderating variables in budgetary participation relationships with budgetary slack. Dewi (2014), research shows the results of higher organizational commitment, causing a decrease in budgetary slack. This illustrates that employees who have high organizational commitment will use the budget to achieve organizational goals. While employees with low organizational commitment will use the budget to pursue their own interests. Based on the theoretical study above, the hypothesis formulated is

H2: Organizational commitment weakens the positive effect of budgetary participation on budgetary slack.

\section{Tri Hita Karana Culture Weakens the Positive Relationship of Budgetary participation at the Budgetary Slack}

Sandrya (2013), states budgetary participation creates an opportunity for central managers of accountability to conduct budgetary slack. However, a strong grip on Tri Hita Karana's cultural values for each manager can provide support for their mindset to always carry out their tasks that are so complex as a process that they are individuals who continue to learn and motivate themselves in gaining knowledge and experience in implementing budgeting planning. They have strong self-confidence that the successful implementation of a budget comes from self-control so that it will 
help managers to improve their performance whatever they do. Previous research such as Adiputra (2014); Mustikayani (2016); and Yudastri et al., (2017), have used the Tri Hita Karana Cultural variable as a moderating variable.

H3: Tri Hita Karana culture weakens the positive influence of budgetary participation on budgetary slack.

\section{Materials and Methods}

\section{Location}

The location of the study in this study is the Regional Devices Organization (OPD) of the Province of Bali. Regional Organization Organization (OPD) was chosen because OPD has the task of compiling, using, reporting budget realization or as budget implementers from the regional government and especially the Bali Provincial government implementing Balinese cultural culture as a guideline to create organizational harmony namely Tri Hita Karana culture.

\section{Population and Samples}

The population of this study is the Head of Section and Subdivision of Regional Organizations (OPD) of the Province of Bali. There are 45 OPDs in the Bali Province environment. Sampling in this study was carried out on a nonprobability sampling basis, namely by using a purposive sampling approach. Purposive sampling is a sampling technique using criteria. The criteria in this study are the Head of Division/Division and Head of Program and Financial Planning Sub-Section who has served for a minimum of two years.

\section{Data Methods}

The data collection method used in this study is a survey method, namely the method of collecting primary data obtained directly from the original source. The researcher used a questionnaire (questionnaire), which is a technique for collecting data and information using a list of statements submitted to respondents regarding the problem to be studied. The statement presented in the questionnaire will be measured using a Likert scale.

Data analysis

The data analysis method used in this study is multiple linear regression containing the interaction or test of the Moderating Regression Analysis (MRA). MRA is used to test the second hypothesis (H2) and the third hypothesis (H3).

\section{Results and Discussions}

\section{MRA testing result}

The results of the regression analysis with the Statistical Package of Social Science (SPSS) program can be seen in Table 1 below:

Table 1

Moderating Regression Analysis (MRA)

\begin{tabular}{|c|c|c|c|c|c|c|}
\hline \multirow{2}{*}{\multicolumn{2}{|c|}{ Model }} & \multicolumn{2}{|c|}{ Unstandardized Coefficients } & \multirow{2}{*}{$\begin{array}{l}\text { Standardized Coefficients } \\
\text { Beta }\end{array}$} & \multirow{2}{*}{$\mathrm{t}$} & \multirow{2}{*}{ Sig. } \\
\hline & & $B$ & Std. Error & & & \\
\hline \multirow[t]{4}{*}{1} & (Constant) & 16,782 & 1,189 & & & 0,000 \\
\hline & Budgetary participants & 1,043 & 0,330 & 0,360 & 3,160 & 0,004 \\
\hline & X_M1 & $-0,101$ & 0,049 & $-0,102$ & $-2,061$ & 0,039 \\
\hline & X_M2 & $-0,441$ & 0,189 & $-0,105$ & $-2,333$ & 0,008 \\
\hline
\end{tabular}

Primary Data, 2019

Based on Table 1 can be written multiple linear regression equation as follows:

$$
\mathrm{Y}=16,782+1,043 \mathrm{X}-0,101 \mathrm{X} \_\mathrm{M}_{1}-0,441 \mathrm{X} \_\mathrm{M}_{2}
$$

Description:

$\mathrm{Y} \quad=$ Budgetary Slack

$\mathrm{X}$ = Budgetary participation

Sukayana, G. A., \& Putri, I. A. D. (2019). Tri hita karana culture and organizational commitments moderate: effect of participation on budgetary slack. International Research Journal of Management, IT and Social Sciences, 6(4), 180-188. https://doi.org/10.21744/irjmis.v6n4.676 
M1 = Organizational commitment

M2 = Tri Hita Karana Culture

\section{The Effect of Budgetary Participation on Budgetary Slack}

Effect of budgetary participation (X) on budgetary slack. Based on Table 1, the results of the analysis of the effect of budgetary participation on budgetary slack obtained sig. $t$ is 0.004 with the beta coefficient value of 1.043 . Sig value t $0.004<0.05$ indicates that $\mathrm{H} 0$ is rejected and $\mathrm{H} 1$ is accepted. This result means that budgetary participation has a positive effect on budgetary slack so that the first hypothesis in this study is accepted.

The results of this study are supported by the results of research by Falikhatun (2008); Mahadewi (2014); Erina (2016); and Wati et al., (2017), which states that participation in budgetary contribution has a positive effect on budgetary slack. This research is also in accordance with the results of the empirical study Sandrya (2013), which states that participation in budgeting in the public sector will create budgetary slack. The argument put forward is that the higher the participation given to subordinates, the subordinates tend to try to make their budget easy to achieve, one way to do that is to loosen the budget or create budgetary slack.

\section{Organizational Commitment on the Positive Relationship of Budgetary Participation at the Budgetary Slack}

Effect of budgetary participation and organizational commitment interactions (X_M1) on budgetary slack. Based on Table 1, the results of the analysis of the effect of the participation of budgetary participation and organizational commitment (X_M1) on budgetary slack obtained the sig value. $t$ is 0.039 with beta coefficient value 0.101 . Sig value t $0.039<0.05$ indicates that $\mathrm{H} 0$ is rejected and $\mathrm{H} 2$ is accepted. This result means that organizational commitment weakens the positive influence of budgetary participation on budgetary slack.

These results are in accordance with the research conducted by Wardani (2016), stating that employees who have a commitment to their organization will work with dedication because employees who have high commitment assume that the important thing to achieve is the achievement of tasks in the organization. These results are also supported by several other studies such as Nouri \& Parker (1996); Lestari (2015); and Nitiari (2014), that have used organizational commitment variables as moderating variables in budgetary participation relationships with budgetary slack.

\section{Tri Hita Karana Culture on the Positive Relationship of Budgetary participation at the Budgetary Slack}

Effect of budgetary participation interaction and Tri Hita Karana culture (X_M2) on budgetary slack. Based on Table 1, the results of the analysis of the effect of budgetary participation interaction and Tri Hita Karana culture (X_M2) on budgetary slack obtained the sig value. $t$ is 0.008 with a beta coefficient of 0.441 . Sig value $t 0.008<0.05$ indicates that $\mathrm{H} 0$ is rejected and $\mathrm{H} 3$ is accepted. This result means that the Tri Hita Karana culture weakens the positive influence of budgetary participation on budgetary slack.

The results of this study are supported by the results of a study by Sandrya (2013), which states budgetary participation creates an opportunity for central managers of accountability to conduct budgetary slack. However, a strong grip on Tri Hita Karana's cultural values for each manager can provide support for their mindset to always carry out their tasks that are so complex as a process that they are individuals who continue to learn and motivate themselves in gaining knowledge and experience in implementing budgeting planning. They have strong self-confidence that the successful implementation of a budget comes from self-control so that it will help managers to improve their performance whatever they do. This research is also in line with the results of other studies such as research conducted by Adiputra (2014); Mustikayani (2016); and Yudastri et al., (2017), who have used the Tri Hita Karana Cultural variable as a moderating variable.

\section{F Test Results}

For the results of the F test, you can see the results of SPSS processed regression by comparing the significance level of each independent variable with $\alpha=0.05$. If a significant level of $\mathrm{F} \alpha \alpha=0.05$ then this model can be said to be feasible. Conversely, if significant $\mathrm{F}>\alpha=0.05$ then the regression equation model can be said to be inappropriate. 
Table 2

F Test

\begin{tabular}{lllllll}
\hline Model & & Sum of Squares & df & Mean Square & F & Sig. \\
\hline 1 & Regression & 136,370 & 3 & 45,457 & 9,294 & $0,000^{\mathrm{b}}$ \\
& Residual & 1457,246 & 168 & 7,222 & & \\
& Total & 1673,616 & 171 & & & \\
\hline
\end{tabular}

Primary Data, 2018

The ANOVA test results or (F test) in Table 2 show the calculated F value of 9,294 with a significance of 0,000 smaller than alpha 0,05 , then the model used in this study is feasible. This shows that budgetary participation (X), the interaction of budgetary participation and organizational commitment (X_M1) and the interaction of budgetary and cultural participation Tri Hita Karana (X_M1) can be used to predict the Budgetary Slack or in other words budgetary participation (X), the interaction of budgetary participation and organizational commitment (X_M1) and the interaction of budgetary and cultural participation of Tri Hita Karana (X_M1) together influence the Budgetary Slack.

\section{Determination Coefficient Test Results (R2)}

Analysis of the coefficient of determination is done to measure how much the independent variable is able to explain the changes in the dependent variable. In this study the coefficient of determination is seen through the Adjust $\mathrm{R}$ Square value shown in Table 3 as follows:

Table 3

Determination Coefficient Test Results $\left(\mathrm{R}^{2}\right)$

\begin{tabular}{lllll}
\hline Model & $R$ & $R$ Square & Adjusted $R$ Square & Std. Error of the Estimate \\
\hline 1 & 0,594 & 0,454 & 0,421 & 1,085 \\
\hline Data Primer, 2019 & & &
\end{tabular}

Based on Table 3 Adjusted R Square of 0.454 means that 45.4 percent of the Budgetary Slack variation is influenced by variations in budgetary participation $(\mathrm{X})$, interaction of budgetary participation and organizational commitment (X_M1) and interaction of budgetary and cultural participation in Tri Hita Karana (X_M1), while the remaining 54.6 percent is explained by other factors not included in the model.

\section{Conclusion}

The results of this study show that budgetary participation has a positive effect on budgetary slack. Therefore, it is better for the Regional Organizations (OPD) to pay more attention to budgetary participation to reduce the level of budget disparities that might occur so that better budget management can be created in the future in the Regional Devices Organization (OPD). The results of the study showing organizational commitment were able to weaken the positive relationship of budgetary participation to budgetary slack. Therefore, it is better for Regional Organizations (OPD) to strengthen their organizational commitment when preparing budgets so that they can minimize the occurrence of budget gaps in Regional Organizations (OPD). The results of the study showing the cultural essence of Tri Hita Karana were able to weaken the positive relationship of budgetary participation to budgetary slack. Therefore, it is better for the Regional Devices Organization (OPD) to apply the Tri Hita Karana concept when drafting a budget so that it can minimize the occurrence of budget gaps in the Regional Devices Organization (OPD).

\section{Research Limitations}

Based on the limitations in this study, it is expected that further research will expand the object of research. In addition, similar research in the future is expected to use other variables as independent variables that are thought to have an influence on the emergence of budget gaps.

Sukayana, G. A., \& Putri, I. A. D. (2019). Tri hita karana culture and organizational commitments moderate: effect of participation on budgetary slack. International Research Journal of Management, IT and Social Sciences, 6(4), 180-188. https://doi.org/10.21744/irjmis.v6n4.676 
Conflict of interest statement and funding sources

The authors declared that they have no competing interest.

Statement of authorship

The authors have a responsibility for the conception and design of the study. The authors have approved the final article.

\section{Acknowledgments}

The authors would like to thank the Editor of IRJMIS for their valuable time, support, and advice in completing the current study. 


\section{References}

Adiputra, I. M. P. (2014). Budaya Tri Hita Karana sebagai Pemoderasi Pengaruh Kompleksitas Tugas terhadap Kinerja Internal Auditor (Studi Pada Kantor Inspektorat di Provinsi Bali). Jurnal Dinamika Akuntansi, 6(2), 191-205.

Aditya, A. G. D., \& Kusuma, M. G. W. (2019). The effect of tri hita karana culture in relationship between work stress and internal auditor performance. International Research Journal of Management, IT and Social Sciences, 6(2), 72-78. https://doi.org/10.21744/irjmis.v6n2.610

Ajibolade, S. O., \& Akinniyi, O. K. (2013). The influence of organisational culture and budgetary participation on propensity to create budgetary slack in public sector organisations. British Journal of Arts and Social Sciences, 13(1), 69-83.

Anthony, R. N., \& Govindjaran, V. (2007). Management Control System. McGraw-Hill: New York.

Aprila, N., \& Selvi, H. (2012). The effect of budgetary participation, assymetry information, budget emphasis and comitment organization to budgetary slack at skpd governmental of bengkulu city.

Brownell, P. (1982). The role of accounting data in performance evaluation, budgetary participation, and organizational effectiveness. Journal of accounting research, 12-27.

Dewi, I. G. A. A. O., Dewi, I. G. A. A. P., Kustina, K. T., \& Prena, G. D. (2018). Culture of tri hita karana on ease of use perception and use of accounting information system. International Journal of Social Sciences and Humanities, 2(2), 77-86. https://doi.org/10.29332/ijssh.v2n2.131

Dewi, N. L. P. S., \& Yasa, G. W. (2014). Analisis Pengaruh Anggaran Partisipatif pada Budgetary Slack dengan Empat Variabel Moderasi (Studi Kasus pada SKPD Kabupaten Badung, Bali). E-Jurnal Ekonomi dan Bisnis Universitas Udayana.

Dewi, N. P., \& Erawati, N. M. A. (2014). Pengaruh Partisipasi Anggaran, Informasi Asimetris, Penekanan Anggaran Dan Komitmen Organisasi Pada Senjangan Anggaran. E-Jurnal Akuntansi, 476-486.

Dunk, A. S. (1993). The effect of budget emphasis and information asymmetry on the relation between budgetary participation and slack. Accounting review, 400-410.

Erina, N. P. D., \& Suartana, W. (2016). Pengaruh Partisipasi Penganggaran, Penekanan Anggaran, Kapasitas Individu, dan Kejelasan Sasaran Anggaran Pada Senjangan Anggaran. E-Jurnal Akuntansi, 973-1000.

Falikhatun, H. (2008). Interaksi Informasi Asimetri, Budaya Organisasi, dan Group Cohesiveness dalam Hubungan Antarapartisipasi Penganggaran dan Budgetary Slack (Studi Kasus pada Rumah Sakit Umum Daerah Se Jawa Tengah). Media Riset Akuntansi, Auditing \& Informasi, 8(1), 65-84.

Govindarajan, V. (1986). Impact of participation in the budgetary process on managerial attitudes and performance: Universalistic and contingency perspectives. Decision Sciences, 17(4), 496-516. https://doi.org/10.1111/j.15405915.1986.tb00240.x

Hapsari, Y. I. (2011). Pengaruh Kapasitas Individu Terhadap Budgetary Slack dengan Self Esteem Sebagai Variabel Moderasi. Skripsi, Fakultas Ekonomi Atma Jaya Yogyakarta.

Hofstede, G. (1991). Cultures and Organizations: software of the mind (London and New York, McGraw Hill). House, RJ, Hanges, PJ, Javidan, M., Dorfman, PW, \& Gupta, V.(Eds. 2004), Airaksinen, 1-25.

Hofstede, G. (2003). What is culture? A reply to Baskerville. Accounting, Organizations and Society, 28(7-8), 811813. https://doi.org/10.1016/S0361-3682(03)00018-7

Jensen, M. C., \& Meckling, W. H. (1976). Theory of the firm: Managerial behavior, agency costs and ownership structure. Journal of financial economics, 3(4), 305-360. https://doi.org/10.1016/0304-405X(76)90026-X

Karsam. (2005). Seni membatik tulis di Kota Bharu, Kelantan, Malaysia dan di Kabuten Tuban, Jawa Timur, Indonesia: satu kajian perbandingan (Doctoral dissertation, Akademi Pengajian Melayu, Universiti Malaya).

Kartiwa, H. A. (2004). Proses Penyusunan Anggaran Pendapatan dan Belanja Daerah (APBD) dan Arah Kebijakan Umum.

Lestari, N. K. T. (2015). Pengaruh Penganggaran Partisipatif pada Senjangan Anggaran Dimoderasi Ketidakpastian Lingkungan Dan Komitmen Organisasi. E-Jurnal Akuntansi Universitas Udayana. 10 (2): 474, 488.

Lukka, K. (1988). Budgetary biasing in organizations: theoretical framework and empirical evidence. Accounting, Organizations and Society, 13(3), 281-301. https://doi.org/10.1016/0361-3682(88)90005-0

Mahadewi, A. A. S. S. Pengaruh partisipasi anggaran pada senjangan anggaran dengan asimetri informasi dan komitmen organisasi sebagai variabel moderasi. E-Jurnal Akuntansi, 458-473.

Merchant, K. A. (1985). Budgeting and the propensity to create budgetary slack. Accounting, Organizations and Society, 10(2), 201-210.

Murray, D. (1990). The performance effects of participative budgeting: An integration of intervening and moderating variables. Behavioral Research in accounting, 2(2), 104-123.

Sukayana, G. A., \& Putri, I. A. D. (2019). Tri hita karana culture and organizational commitments moderate: effect of participation on budgetary slack. International Research Journal of Management, IT and Social Sciences, 6(4), 180-188. https://doi.org/10.21744/irjmis.v6n4.676 
Musktikayani, N. L. P. D., \& Dwirandra, A. A. N. B. Budaya tri hita karana sebagai pemoderasi kompleksitas tugas dan tekanan waktu terhadap kinerja auditor. E-Jurnal Akuntansi, 1544-1573.

Nitiari, N. L. N., \& Yadnyana, K. (2015). Pengaruh Partisipasi Penganggaran, Komitmen Organisasi, Dan Ketidakpastian Lingkungan Pada Senjangan Anggaran. E-Jurnal Akuntansi, 143-154.

Nouri, H., \& Parker, R. J. (1996). The effect of organizational commitment on the relation between budgetary participation and budgetary slack. Behavioral research in Accounting, 8, 74-90.

Pamungkas, I. M. B. W., ADIPUTRA, I. M. P., SE, S., Si, M., \& Sulindawati, N. L. G. E. (2014). Pengaruh partisipasi anggaran, informasi asimetri, budaya organisasi, kompleksitas tugas, reputasi, etika dan self esteem terhadap budgetary slack (studi pada satuan kerja perangkat daerah kabupaten jembrana). JIMAT (Jurnal Ilmiah Mahasiswa Akuntansi) Undiksha, 2(1).

Pratiwi, I. Y., Ratnadi, N. M. D., Suprasto, H. B., \& Sujana, I. K. (2019). The effect of role conflict, role ambiguity, and role overload in burnout government internal supervisors with tri hita karana culture as moderation. International Research Journal of Management, IT and Social Sciences, 6(3), 61-69. https://doi.org/10.21744/irjmis.v6n3.630

Schiff, M., \& Lewin, A. Y. (1970). The impact of people on budgets. The Accounting Review, 45(2), $259-268$.

Srimuliani, N. L., Musmini, L. S., SE, A., Si, M., Herawati, N. T., \& AK, S. (2014). Pengaruh partisipasi anggaran, komitmen organisasi, dan job relevant information (jri) terhadap senjangan anggaran (budgetary slack)(Studi Empiris pada Satuan Kerja Perangkat Daerah di Kabupaten Buleleng). JIMAT (Jurnal Ilmiah Mahasiswa Akuntansi) Undiksha, 2(1).

Su, C. C., \& Ni, F. Y. (2013). Budgetary participation and slack on the theory of planned behavior. International Journal of Organizational Innovation (Online), 5(4), 91.

Sugiwardani, R. (2012). Analisis Pengaruh Partisipasi Anggaran, Informasi Simetris, Budaya dan Komitmen Organisasi Terhadap Budgetary Slack (Doctoral dissertation, STIE Perbanas Surabaya).

Sujana, I. K. (2010). Pengaruh partisipasi penganggaran, penekanan anggaran, komitmen organisasi, asimetri informasi, dan ketidakpastian lingkungan terhadap budgetary slack pada hotel-hotel berbintang di Kota Denpasar. Jurnal Ilmiah Akuntansi Dan Bisnis.

Tagwireyi, F. (2012). An evaluation of budgetary slack in public institutions in Zimbabwe. International Journal of Academic Research, 12(4), 38-41.

Wati, I. D. A. K. S., Sinarwati, N. K., Atmadja, A. T., \& SE, A. (2017). Pengaruh Partisipasi Anggaran, Komitmen Organisasi, Budaya Organisasi, dan Pengendalian Internal Terhadap Kesenjangan Anggaran Pada Subak di Kabupaten Jembrana.(Study Empiris Antara Subak Tegalwangi, Kelurahan Dauhwaru, Subak Sawe Dauh Tukad, Kelurahan Dauhwaru dan Subak Sangkaragung, Kelurahan Sangkaragung). JIMAT (Jurnal Ilmiah Mahasiswa Akuntansi) Undiksha, 7(1).

Wiyantoro, L. S., \& Sabeni, A. (2007). Hubungan Antara Sistem Pengendalian Manajemen Dengan Perilaku Dysfunctional: Budaya Nasional Sebagai VariabelModerating. Simposium Nasional Akuntansi X, 1-35.

Yasa, S. M. A. S. W., \& Badera, I. D. N. (2016). Peran komitmen organisasi dan satuan kerja perangkat daerah dalam memoderasi pengaruh partisipasi penganggaran pada senjangan anggaran. E-Jurnal Ekonomi dan Bisnis Universitas Udayana.

Yilmaz, E., \& Özer, G. (2011). The effects of environmental uncertainty and budgetary control effectiveness on propensity to create budgetary slack in public sector. African Journal of Business Management, 5(22), 8902-8908.

Young, S. M. (1985). Participative budgeting: The effects of risk aversion and asymmetric information on budgetary slack. Journal of accounting research, 829-842.

Yudastri, N. K., Budiartha, I. K., \& Badera, I. D. N. (2017). Budaya Tri Hita Karana sebagai Pemoderasi Pengaruh Penganggaran Partisipatif, Pengendalian Anggaran dan Standar Operasional Prosedur pada Perilaku Disfungsional. Buletin Studi Ekonomi, 89-99. 